\title{
If your hospital has RATS, do not exterminate
}

\author{
Moishe Liberman, MD, PhD
}

\footnotetext{
From the Division of Thoracic Surgery, University of Montréal, Montréal, Québec, Canada; and the CETOC (CHUM Endoscopic Tracheobronchial and Oesophageal Center), Centre Hospitalier de l'Université de Montréal, Montréal, Québec, Canada.

Disclosures: Author has nothing to disclose with regard to commercial support.

Received for publication Sept 10, 2017; accepted for publication Sept 16, 2017; available ahead of print Oct 15 , 2017.

Address for reprints: Moishe Liberman, MD, PhD, Division of Thoracic Surgery, Centre Hospitalier de l'Université de Montréal, 1560 rue Sherbrooke Est, 8e CD, Pavillon Lachapelle, Bureau D 8051, Montréal, Québec, Canada H2L 4M1 (E-mail: moishe.liberman@umontreal.ca).

J Thorac Cardiovasc Surg 2018;155:777

$0022-5223 / \$ 36.00$

Copyright (C) 2017 by The American Association for Thoracic Surgery

https://doi.org/10.1016/j.jtcvs.2017.09.081
}

In this edition of the Journal, Cerfolio and colleagues ${ }^{1}$ report on the largest retrospective series of robotically assisted thoracoscopic surgical (RATS) lobectomy for nonsmall cell lung cancer with long-term follow-up from 4 institutions. Data such as these are important in terms of benchmarking, demystifying, and proving long-term oncologic safety of the technique. The ability to report complete follow-up for $99 \%$ of patients is more than excellent and lends to the power of the study.

Stage-specific survival was excellent; however, this should not be interpreted by the reader to mean that RATS is a superior oncologic procedure to video-assisted thoracoscopic surgery (VATS) or thoracotomy. This study is retrospective, and there is no information in the article regarding case selection for RATS instead of VATS or thoracotomy in these institutions during the study period. There is no way to know or to control for the patients who underwent lobectomy during the same time period with techniques other than RATS and whether this was due to tumoral or anatomic factors that placed the patients at higher risk for poor surgical and oncologic outcomes (hilar position of tumors, larger tumors, multiple N1 disease, pleural invasion, previous lobectomy or thoracic procedure on the ipsilateral side, thoracic or mediastinal radiation, immunosuppression, anticoagulation, pulmonary hypertension, poor cardiopulmonary function, etc).

It is universally accepted that minimally invasive lobectomy should be the standard of care for stage 1 non-small cell lung cancer. Acceptable techniques include VATS and RATS. Within these 2 approaches there are many different setups and port placements (single-port, 2-port, 3-port, multiport, subxyphoid, transcervical, etc) and port sizes $(3 \mathrm{~mm}$, $5 \mathrm{~mm}, 8 \mathrm{~mm}, 10 \mathrm{~mm}, 12 \mathrm{~mm}, 2 \mathrm{~cm}, 3 \mathrm{~cm}, 4 \mathrm{~cm}, 5 \mathrm{~cm}$, etc). is chosen. ${ }^{2}$

\section{References} 4993-7. 425-6.

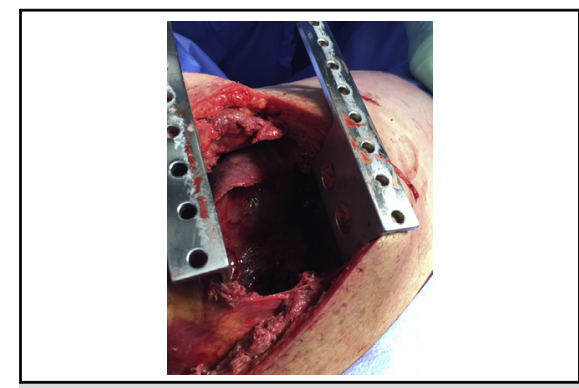

Lobectomy by thoracotomy-historical interest only?

Central Message

The largest series of robotic lobectomy for non-small cell lung cancer to date provides good data and long-term follow-up regarding the safety and long-term oncologic outcomes of the procedure.

See Article page 778 .

The approach, port placement, port size, and technical differences probably make little difference to the patient, as long as a minimally invasive approach without rib spreading

The $9 \%$ conversion rate seems high when compared with VATS series; however, there is a learning curve here, and this should have decreased with time (data not reported). The conversion rate for VATS lobectomy in a large series reported by McKenna and colleagues ${ }^{3}$ from an experienced center was $2.5 \%$. It is obvious that RATS is equivalent to VATS in terms of long-term oncologic outcome and safety. The question that remains to be answered is whether the cost of the procedure can be justified.

1. Cerfolio RJ, Ghanim AF, Dylewski M, Veronesi G, Spaggiari L, Park BJ. The long-term survival of robotic lobectomy for non-small cell lung cancer: a multiinstitutional study. J Thorac Cardiovasc Surg. 2018;155:778-86.

2. Swanson SJ, Herndon JE II, D'Amico TA, Demmy TL, McKenna RJ Jr, Green MR, et al. Video-assisted thoracic surgery lobectomy: report of CALGB 39802 - a prospective, multi-institution feasibility study. J Clin Oncol. 2007;25:

3. McKenna RJ Jr, Houck W, Fuller CB. Video-assisted thoracic surgery lobectomy: experience with 1,100 cases. Ann Thorac Surg. 2006;81:421-5; discussion 